$$
\text { D. } 542
$$

RFP-2033

ecember 27,1973

RFP-2033
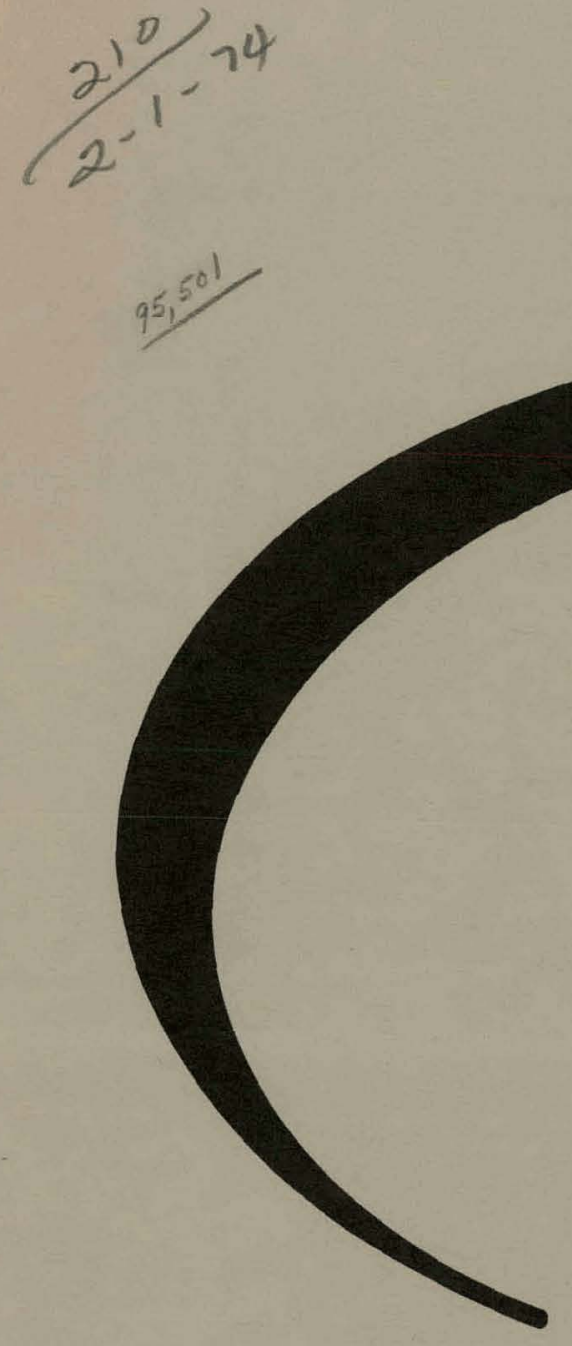

\title{
THE CORROSION AND STRESS-CORROSION \\ CRACKING OF WELDED \\ URANIUM-6 WEIGHT PERCENT NIOBIUM
}

James M. Macki

Robert L. Kochen

\section{Dow}

(6)

DOW CHEMICAL U.S.A. ROCKY FLATS DIVISION

P. O. BOX 888

GOLDEN, COLORADO 80401

U. S. ATOMIC ENERGY COMMISSION CONTRACT AT(29-1)-1106 


\section{DISCLAIMER}

This report was prepared as an account of work sponsored by an agency of the United States Government. Neither the United States Government nor any agency Thereof, nor any of their employees, makes any warranty, express or implied, or assumes any legal liability or responsibility for the accuracy, completeness, or usefulness of any information, apparatus, product, or process disclosed, or represents that its use would not infringe privately owned rights. Reference herein to any specific commercial product, process, or service by trade name, trademark, manufacturer, or otherwise does not necessarily constitute or imply its endorsement, recommendation, or favoring by the United States Government or any agency thereof. The views and opinions of authors expressed herein do not necessarily state or reflect those of the United States Government or any agency thereof. 


\section{DISCLAIMER}

Portions of this document may be illegible in electronic image products. Images are produced from the best available original document. 


\section{LEGAL NOTICE}

This report was prepared as an account of work sponsored by the United States Government. Ncither the United States nor the United States Atomic Energy Commission, nor any of their employees, nor any of their contractors, subcontractors, or their employees, makes any warranty, expressed or implied, or assumes any legal liability or responsibility for the accuracy, completeness or usefulness of any information, apparatus, product or process disclosed, or represents that its use would not infringe privately owned rights.

Printed in the United States of America

Available from the

National Technical Information Service

U. S. Department of Commerce

Springfield, Virginia 22151

Price: Printed Copy $\$ 4.00$ Microfiche $\$ 1.45$ 


\section{THE CORROSION AND STRESS-CORROSION CRACKING OF WELDED URANIUM-6 WEIGHT PERCENT NIOBIUM} James M. Macki

Robert L. Kochen

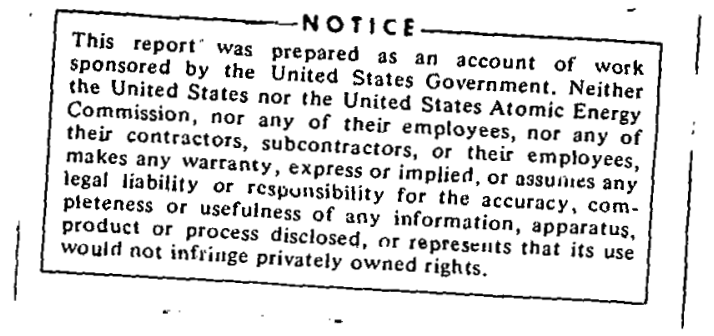

DOW CHEMICAL U.S.A. ROCKY FLATS DIVISION

P. O. BOX 888 GOLDEN, COLORADO 80401

Prepared under Contract AT(29.1)-1106

for the

Albuquerque Operations Office

U. S. Atomic Energy Commission

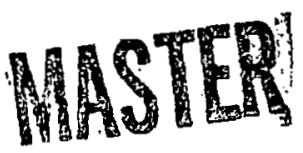


RFP-2033 


\section{CONTENTS}

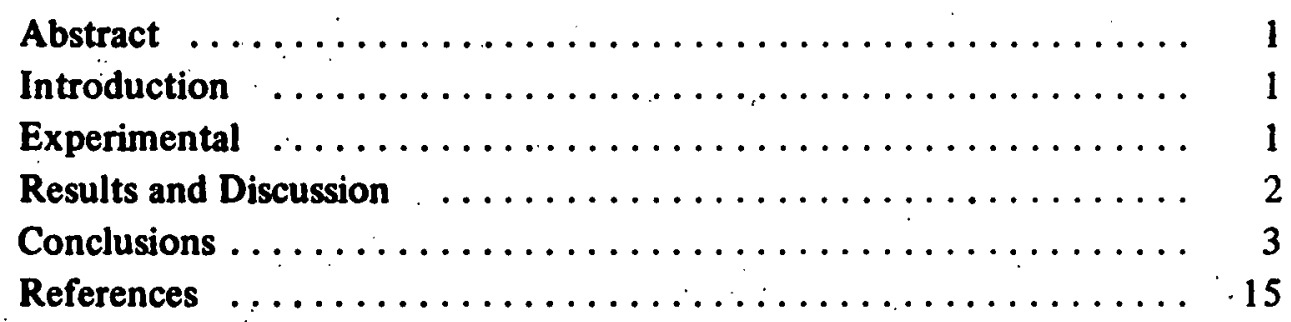


RFP-2033 


\title{
THE CORROSION AND STRESS-CORROSION CRACKING OF WELDED \\ URANIUM-6 WEIGHT PERCENT NIOBIUM
}

\author{
James M. Macki and Robert L. Kochen
}

\begin{abstract}
The resistance of corrosion and stresscorrosion cracking of welded U-6 wt $\% \mathrm{Nb}$ in oxygen-saturated water containing $50 \mathrm{ppm}$ chloride ions was investigated. The tests showed that a post-weld heat treatment consisting of solution quenching and underaging $\left(350^{\circ} \mathrm{C}\right.$ for $42 \mathrm{~min}$.) provided the best resistance to corrosion and pitting corrosion. Although selective corrosion and pitting corrosion were observed on many of the specimens tested, no evidence of stresscorrosion cracking was found.
\end{abstract}

\section{INTRODUCTION}

U-base alloys have been shown to be susceptible to stress-corrosion cracking (SCC). ${ }^{1-10}$ Two modes of stress-corrosion crack propagation, intergranular and transgranular, and a mixed transgranular and intergranular SCC mode have been observed. ${ }^{1,5,7,8}$ The simultaneous presence of chloride ions, oxygen, and moisture appear to be required for the nucleation and/or propagation of intergranular stress-corrosion cracks in $\mathrm{U}-\mathrm{Nb}$ and $\mathrm{U}-\mathrm{Nb}-\mathrm{Zr}$ alloys. ${ }^{1,8,10}$ The U-6 wt\% Nb binary alloy has possible applications that would involve welding of the alloy.

The welding operation used on U-6 wt $\% \mathrm{Nb}$ alloy parts could produce residual stresses that would render the material susceptible to SCC in environments containing chloride ions, moisture, and oxygen. The welded material could also be susceptible to localized or selective corrosion through the welded microstructure.

This investigation was undertaken to determine whether the as-welded material is susceptible to selective corrosion or SCC and to determine how these susceptibilities are affected by post-weld heat treatments and post-weld machining.

\section{EXPERIMENTAL}

The SCC tests utilized welded cylinders of U-6 wt\% Nb that were welded in the solutionquenched (gamma-quenched) condition.

The cylinders were obtained from forward-extruded tubes. Each cylinder had a 6-in. outside diameter and a 0.125 -in. wall thickness. The 6-in.-high cylinder was made by welding two 3-in.-high cylinders together using full-penetration gastungsten-arc (GTA) welds.

The post-weld heat treatments and surface treatments were selected for this study by E. D. Brandon and are summarized in Table $1 .^{11}$ The post-weld heat treatments, which were selected by J. F. Boland, ${ }^{11}$ include solution quench (solutionize at $800^{\circ} \mathrm{C}$ for $5 \mathrm{~min}$. and water quench), underage

Table 1. Welded U-6 wt\% Nb Test Parameters.

\begin{tabular}{|c|c|c|c|}
\hline Cylinder ${ }^{a}$ & Weldingb & $\begin{array}{c}\text { Post-Weld } \\
\text { Heat Treatment }\end{array}$ & $\begin{array}{c}\text { Post-Weld } \\
\text { Surface Treatment }\end{array}$ \\
\hline $38,39,40$ & GTA & None & None \\
\hline $22,23,24$ & GTA & None & Machined \\
\hline $34,35,37$ & GTA & $\begin{array}{l}\gamma \text {-quenchc } \\
\text { tunderaged }\end{array}$ & Machined \\
\hline $31,32,33$ & GTA & $\begin{array}{l}\gamma \text {-quench } \\
\text { toverage }\end{array}$ & Machined \\
\hline $42,43,44$ & GTA & Overage & Machined \\
\hline $27,28,29$ & GTA & $\gamma$-quench & Machined \\
\hline $45,46,47$ & GTA-Tack & None & None \\
\hline
\end{tabular}

aCylinder numbers are those assigned during fabrication. bGTA designates gas-tungsten-arc, single pass welds.

$\mathrm{c}_{\boldsymbol{\gamma}}$-quench denotes solutionizing at $800^{\circ} \mathrm{C}$ for 5 minutes followed by a water quench.

dUnderage denotes aging at $350^{\circ} \mathrm{C}$ for 42 minutes followed by a water quench.

e Overage denotes aging at $575^{\circ} \mathrm{C}$ for 22 minutes followed by a water quench. 
(age at $350^{\circ} \mathrm{C}$ for $42 \mathrm{~min}$. and water quench), and overage (age at $575^{\circ} \mathrm{C}$ for $22 \mathrm{~min}$. and water quench).

The welded cylinders were tested for SCC by immersing them in oxygen-saturated water containing $50 \mathrm{ppm}$ chloride ions. The solution was prepared by adding $\mathrm{NaCl}$ to distilled water to achieve a $50 \pm 1 \mathrm{ppm}$ chloride ion concentration, and oxygen saturation $(8.2 \pm 0.3 \mathrm{ppm}$ oxygen $)$ was achieved by bubbling oxygen through the water during the test. All tests were at room temperature $\left(26 \pm 2^{\circ} \mathrm{C}\right)$.

The tests involved three 30 -day test periods for a total of 90 days. The $50 \mathrm{ppm}$ chloride ion solution was changed after each 30 -day test period. After the first and third 30-day test periods, the cylinders were cleaned and $\mathrm{x}$-radiographed. At the end of the 90-day test, some of the cylinders were cut up to provide specimens for metallographic and chemical analyses.

\section{RESULTS AND DISCUSSION}

Results of the chemical analyses of parent metal and fusion zone samples taken from welded cylinders after the 90-day tests are shown in Table 2.

Table 2. Results of Chemical Analyses Tests on Parent Metal and Fusion Zones of Welded Cylinders.

\begin{tabular}{|c|c|c|c|c|c|c|}
\hline \multirow[b]{2}{*}{ Sample } & \multirow[b]{2}{*}{$\mathrm{Wt} \% \mathrm{Nb}$} & \multicolumn{5}{|c|}{ Concentration (ppm) } \\
\hline & & C & $\mathrm{H}$ & $\mathrm{N}$ & 0 & $\mathrm{~s}$ \\
\hline 22 Parent & 5.40 & 205 & 5,9 & 107 & 101 & 45 \\
\hline 22 Weld & 5.00 & 220 & $3,11,3$ & - & - & 50 \\
\hline 27 Parent & 5.08 & 170 & 7,3 & 75 & 70 & 60 \\
\hline 27 Weld & 4.96 & 485 & 17,25 & - & - & - \\
\hline 31 Parent & 5.48 & 195 & 7,25 & 82 & 240 & 45 \\
\hline 31 Weld & 5.44 & 220 & 5,6 & - & - & 50 \\
\hline 34 Parent & 5.28 & 310 & 25,24 & 121 & 1000 & 45 \\
\hline 38 Parent & 5.16 & 180 & $30,16,6$ & 88 & 70 & 50 \\
\hline 38 Weld & 5.12 & 240 & $21,58,148$ & - & & 60 \\
\hline 42 Parent & 5.48 & 200 & 9,20 & 51 & 850 & 40 \\
\hline 42 Weld & 5.12 & 270 & 29,34 & - & & 80 \\
\hline
\end{tabular}

Hardness transverses across cross-sections of the welds were made with measurements taken at the positions shown in Figure 1. Results of these hardness measurements are shown in Table 3.

Photomicrographs of U-6 wt $\%$ Nb welds, heataffected zones (HAZ), and parent metal are shown in Figures 2 through 7. Figure 8 shows a welded cylinder after a 30-day immersion in oxygensaturated water containing $50 \mathrm{ppm}$ chloride ions.

Selected x-radiographs are shown in Figures 9 through 16. The light spots in the radiographs are corrosion pits. Some of the $\mathrm{x}$-radiographs of machined specimens show a light band about 1 to 2 in. wide where the surface was machined (e.g., Figures 10 and 11). The absence of light

Figure 1. Positions of Hardness Measurements Across U-6 wt\% Nb Welds.

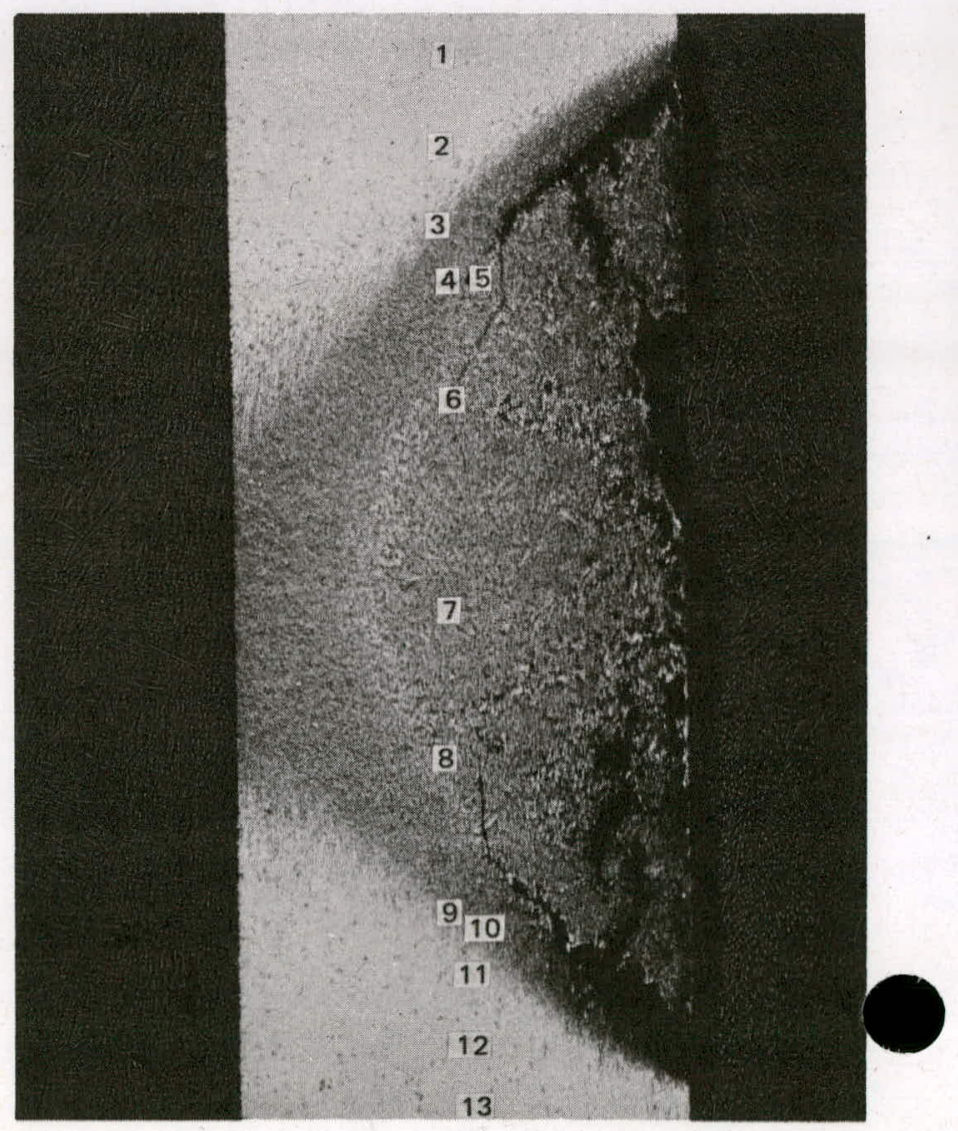


Table 3. Hardness Measurements Across Welds at Positions Shown in Figure 1.

\begin{tabular}{|c|c|c|c|c|c|c|}
\hline \multirow[b]{2}{*}{ Position ${ }^{\mathrm{a}}$} & \multicolumn{6}{|c|}{ Hardness (Knoop, $500 \mathrm{~g}$ load) $\mathrm{b}$} \\
\hline & No. 22 & No. 38 & No. 27 & No. 34 & No. 31 & No. 42 \\
\hline $1 \mathrm{PM}$ & 217 & 209 & 162 & 418 & 355 & 475 \\
\hline 2 PM & 192 & 212 & 172 & 432 & 370 & 488 \\
\hline 3 PM & 178 & 214 & 173 & 442 & 365 & 450 \\
\hline $4 \mathrm{HAZ}$ & 190 & 218 & 152 & 432 & 390 & 478 \\
\hline $5 \mathrm{HAZ}$ & 192 & 224 & 173 & 460 & 390 & 480 \\
\hline 6 WELD & 196 & 204 & 266 & 452 & 400 & 488 \\
\hline 7 WELD & 215 & 266 & 250 & 460 & 390 & 462 \\
\hline 8 WELD & 220 & 250 & 258 & 450 & 390 & 473 \\
\hline $9 \mathrm{HAZ}$ & 210 & 244 & 208 & 437 & 390 & 460 \\
\hline $10 \mathrm{HAZ}$ & 208 & 224 & 197 & 444 & 390 & 470 \\
\hline $11 \mathrm{PM}$ & 205 & 244 & 200 & 457 & 365 & 473 \\
\hline $12 \mathrm{PM}$ & 200 & 200 & 178 & 448 & 380 & 473 \\
\hline $13 \mathrm{PM}$ & 197 & 202 & 188 & 448 & 365 & 445 \\
\hline
\end{tabular}

aPM denotes parent metal; HAZ denotes heat-affected zone; and WELD denotes fusion zone of weld.

bNo. 22 and No. 38 are as-welded; No. 27 is solution quenched; No. 34 solution quenched and underaged; No. 31 is solution quenched and overaged; and No. 42 is overaged.

spots (corrosion pits) indicates uniform corrosion (e.g., Figure 11).

Figures 2 and 3 (as-welded) show selective corrosion similar to knife-line attack (KLA) along the bond line of the weld. The as-machined surface (Figure 3) also exhibited general corrosion of the fusion zone. The X-radiograph of the as-welded specimens (Figure 9) shows the as-welded specimen was subject to pitting corrosion in the HAZ and parent metal in addition to general corrosion of the fusion zone and KLA along the bond line.

The x-radiograph of the machined only (as-welded microstructure) specimen in Figure 10 shows that machining the surface reduces the amount of pitting corrosion. The contrast within the fusion zone shown in Figure 10 indicates some chemical inhomogeneity.

The solution-quenched and machined-after-welding treatment (Figures 4 and 11) did not affect the corrosion of the fusion zone and bond line (Figure 4a).
The post-weld treatment resulting in the most resistance to corrosion and pitting corrosion was post-weld solution quenching, underaging, and machining as shown in Figures 5, 12, and 13. The $\mathrm{x}$-radiograph in Figure 12 shows no pitting. The $\mathrm{x}$-radiograph in Figure 13 shows corrosion pits but they are uniformly distributed independently of the weld region.

The specimens that were solution quenched, overaged, and machined after welding exhibited pitting corrosion to the parent metal (Figure 14) and selective corrosion along the bond line and in the fusion zone (Figure 6).

The specimens that were not solution quenched after welding but only overaged and machined exhibited general corrosion and pitting corrosion which was independent of the weld zone (Figures 7 and 15$)$.

An x-radiograph of GTA tack weld is shown in Figure 16. The $\mathrm{x}$-radiograph shows a ring of pits around the weld in the HAZ that is similar to the lines of pits observed for the as-welded specimens in Figure 9. The welds were also subject to selective or knife-line corrosion that resulted in several fusion cones being detached. To provide satisfactory corrosion resistance, the tack welds would have to be annealed.

\section{CONCLUSIONS}

The post-weld heat treatment producing the most corrosion resistant binary material is solution quenching followed by aging at $350^{\circ} \mathrm{C}$ for 42 minutes (underaging).

Although selective corrosion and pitting were observed, no evidence of stress-corrosion cracking was found on any of the welded specimens. 
RFP-2033

Figure 2. Photomicrographs of Specimen Number 22. Machined after welding-as-welded microstructure.

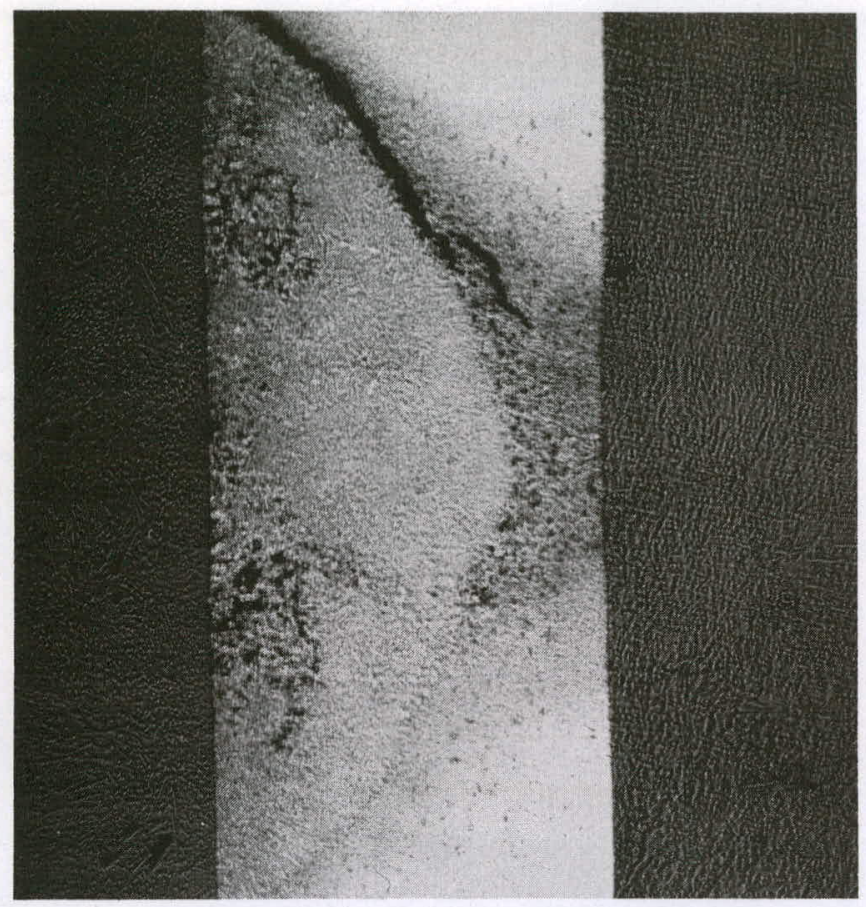

Figure 2a. Note the selective corrosion or KLA (knife-line attack) along bond line and lack of full penetration. 20X.

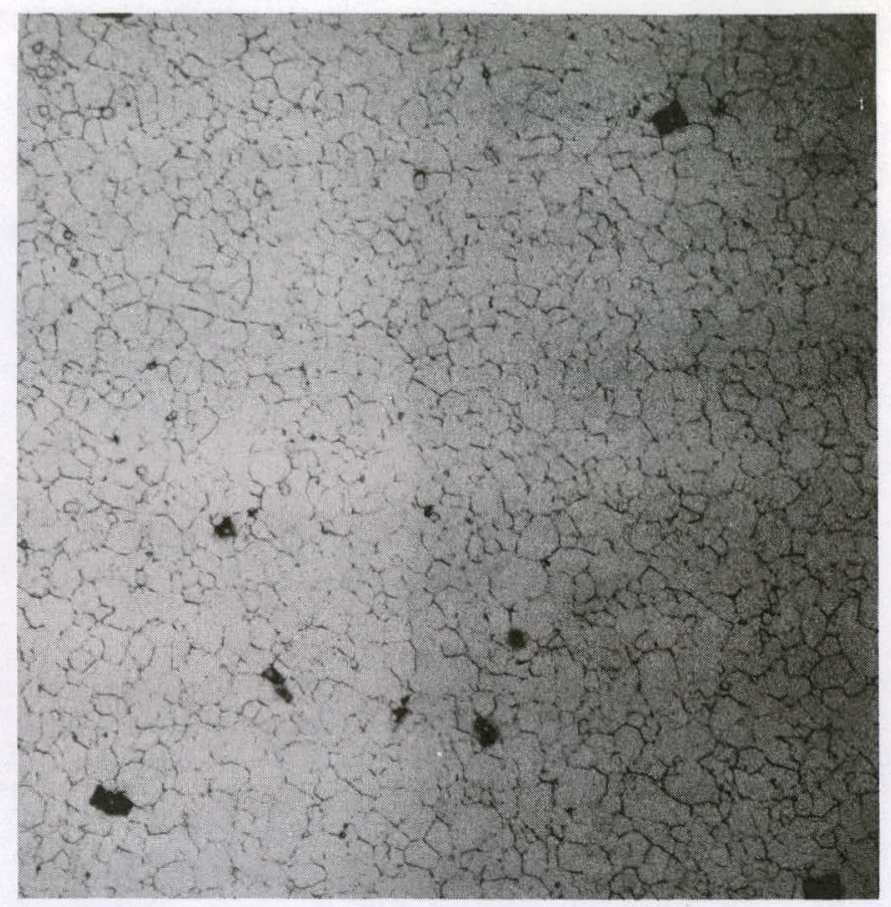

Figure 2b. Parent metal microstructure. 100x.

Figure 2c. Heat affected zone (HAZ) microstructure. 100X.

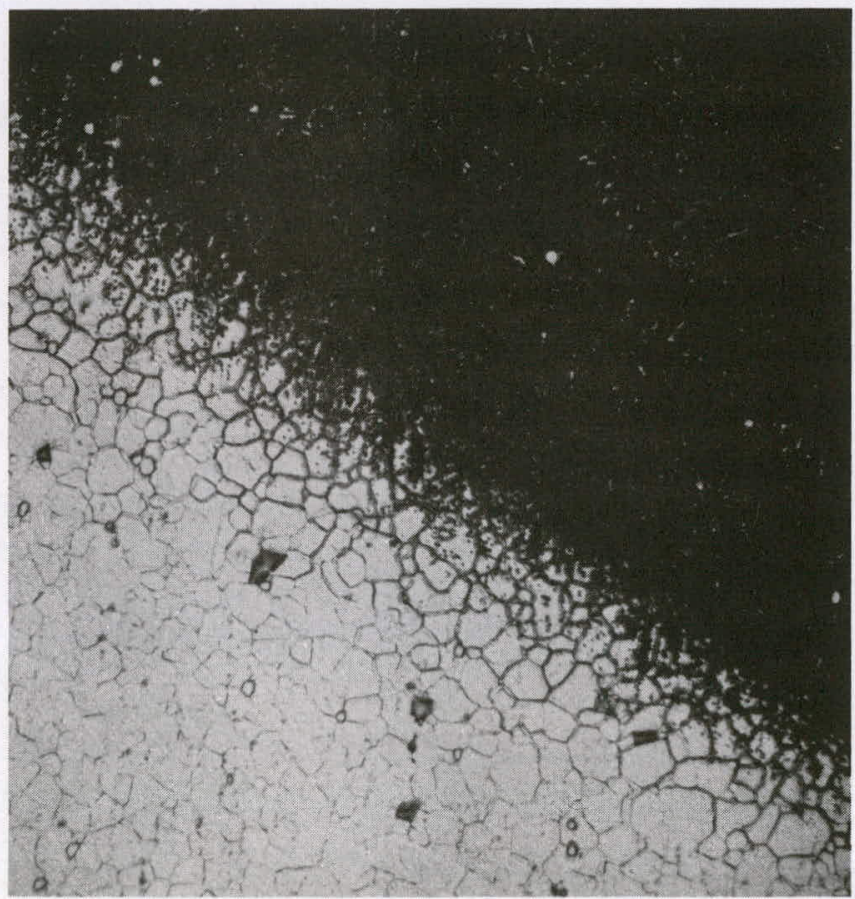


Figure 3. Photomicrographs of Specimen Number 38. As-welded.

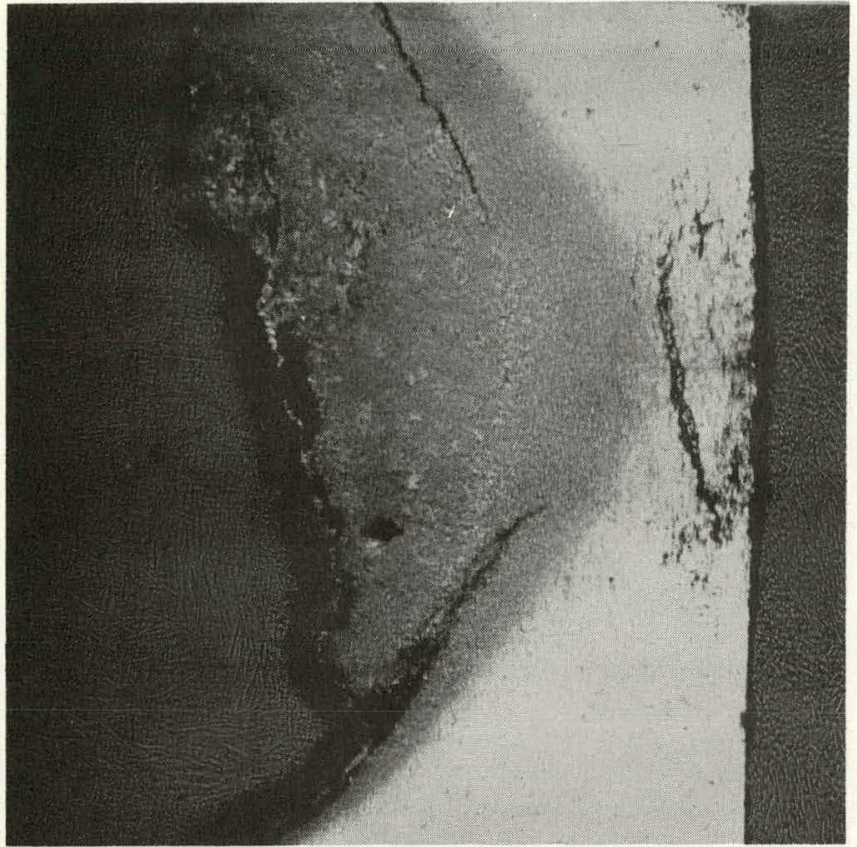

Figure 3a. Note the selective corrosion along bond line and weld material lost by corrosion. 20X.

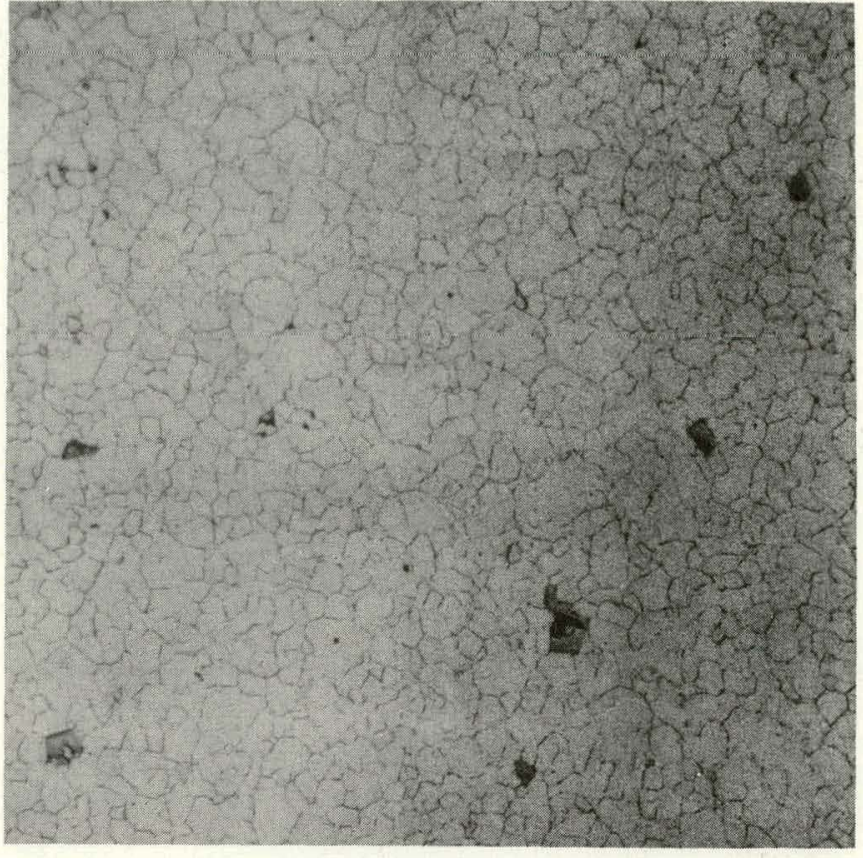

Figure 3b. Parent metal microstructure. 100X.

Figure 3c. HAZ microstructure. 100X.

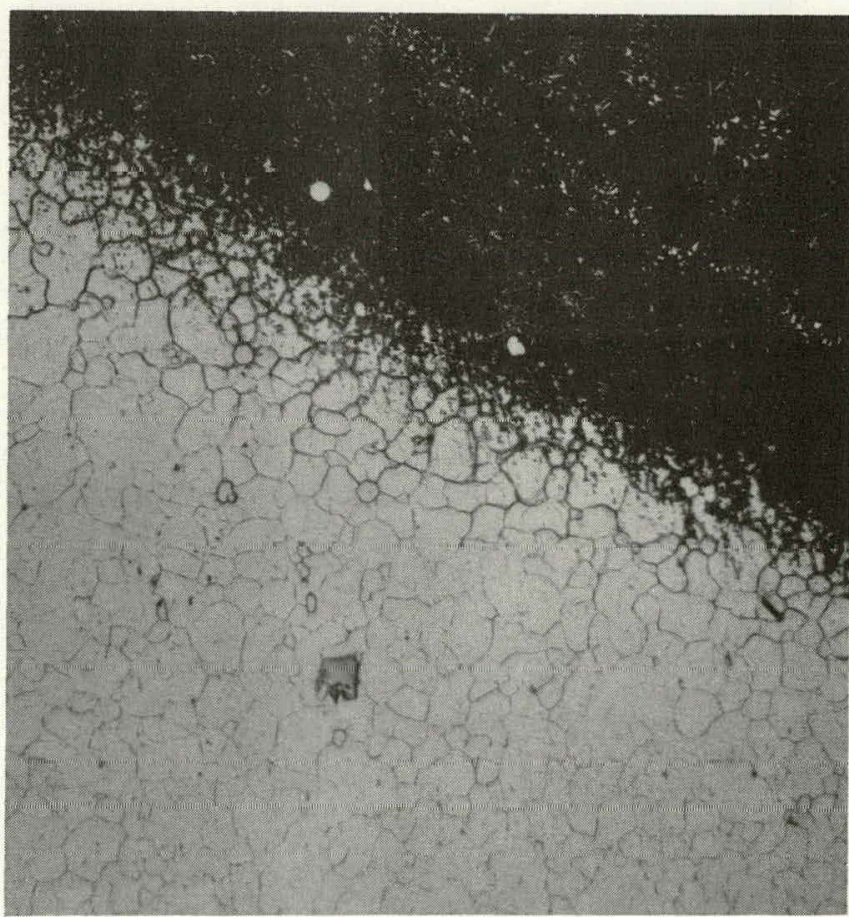


RFP-2033

Figure 4. Photomicrographs of Specimen Number 27. Solution quenched and machined after welding.

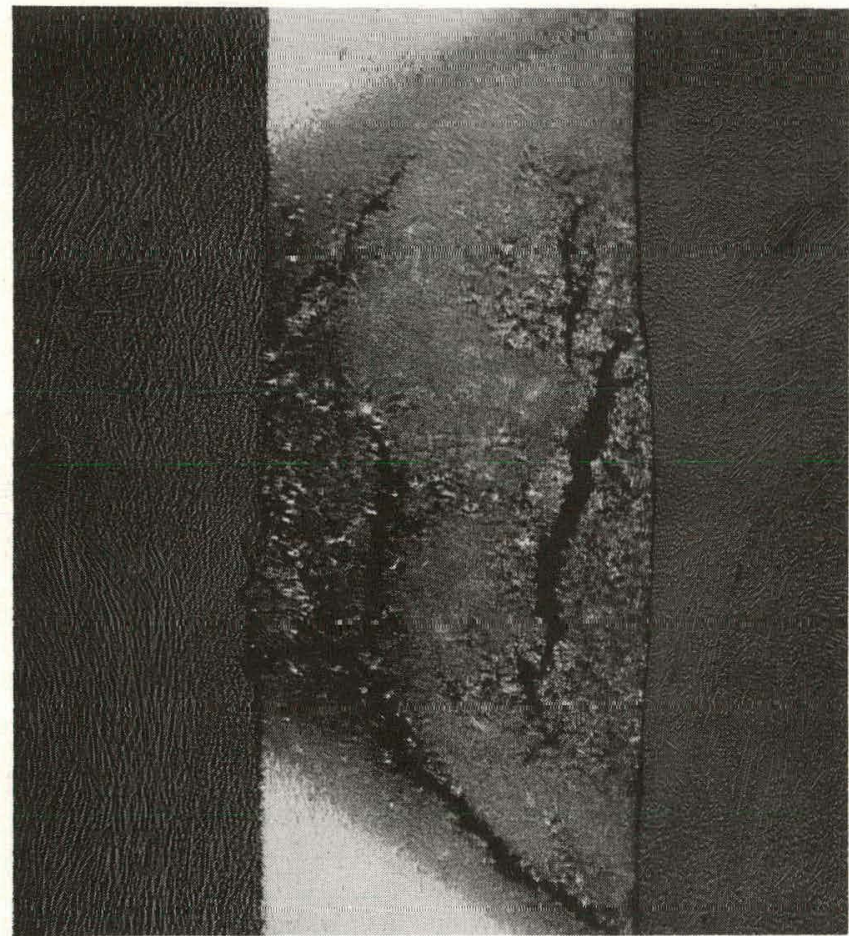

Figure 4a. Note the corrosion along bond line and within weld. 20X.

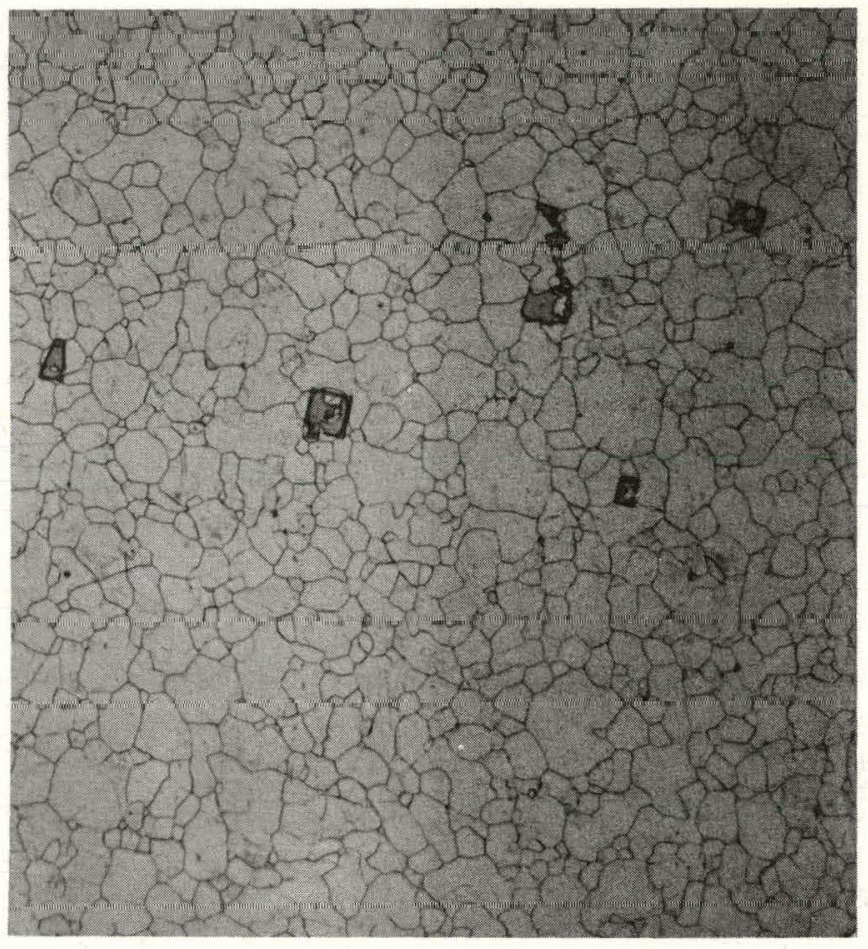

Figure 4b. Parent metal microstrucutre. 100x.

Figure 1c. $\mathrm{H} \wedge \mathrm{Z}$ microsturcture. 100X.

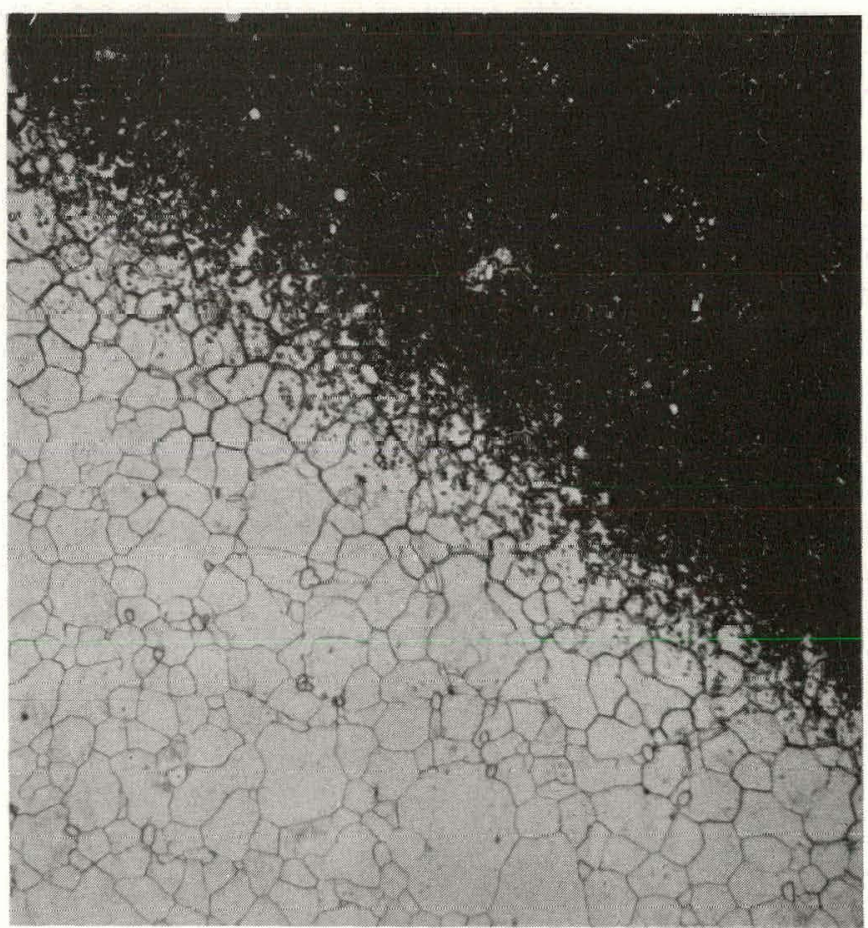


Figure 5. Photomicrographs of Specimen Number 34. Solution quenched, underaged, and machined after welding.

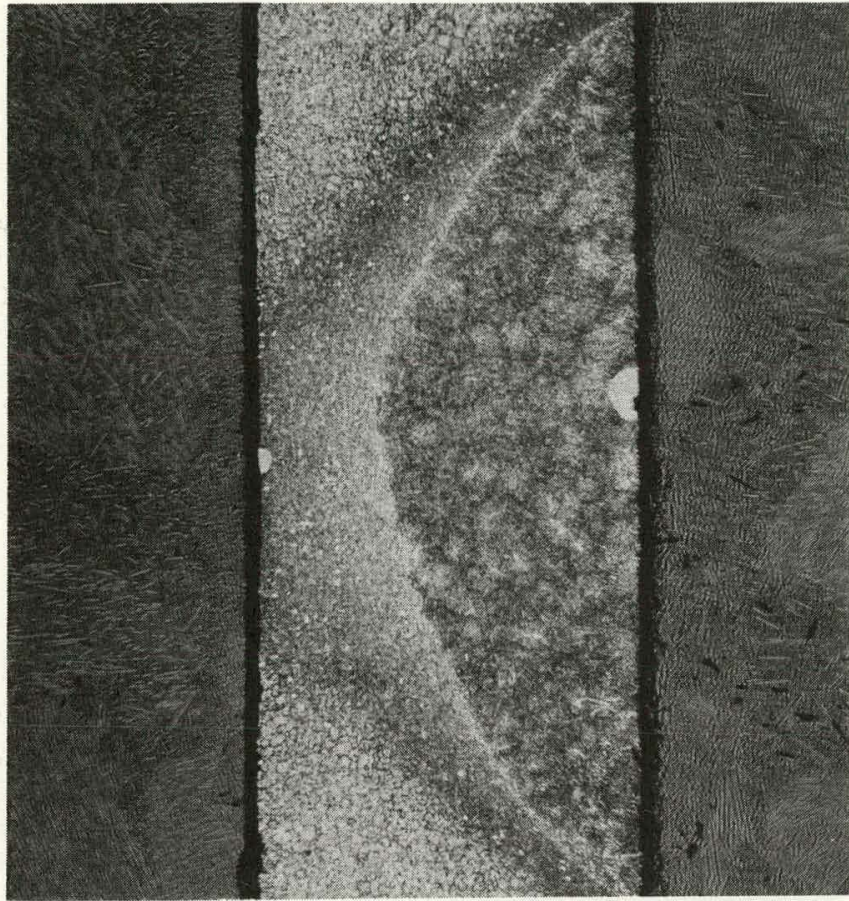

Figure 5a. Note the lack of full penetration and absence of selective corrosion. 20X.

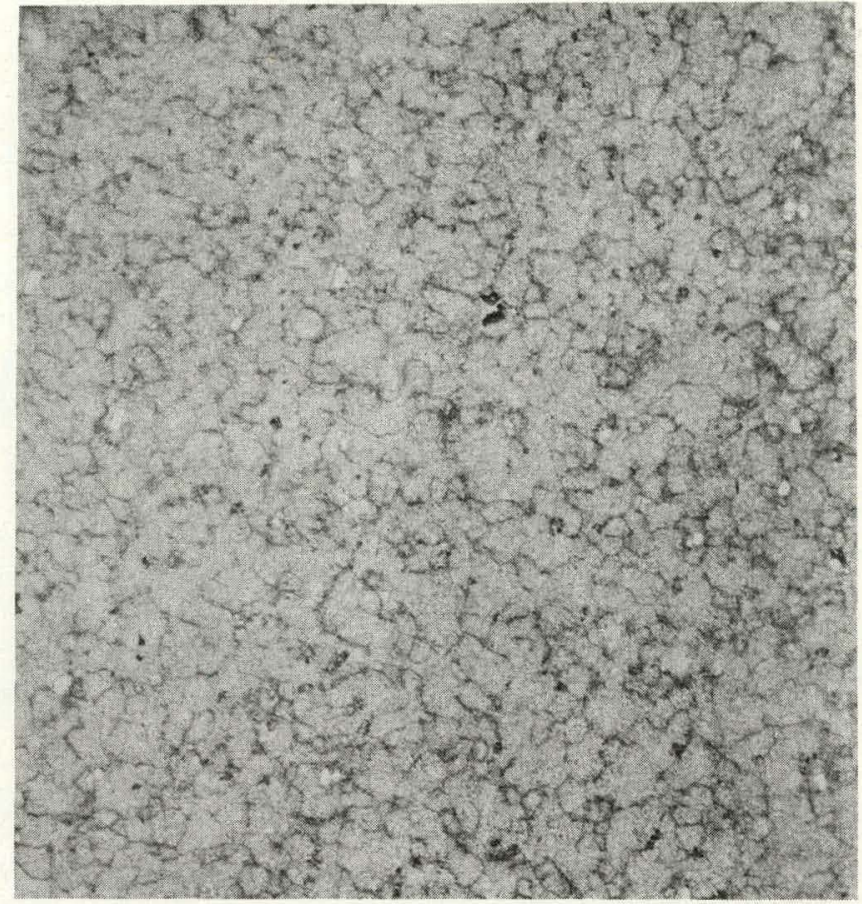

Figure $5 \mathrm{~b}$. Microstructure of parent metal, 100X.

Figure 5c. HAZ microstructure. 100X.

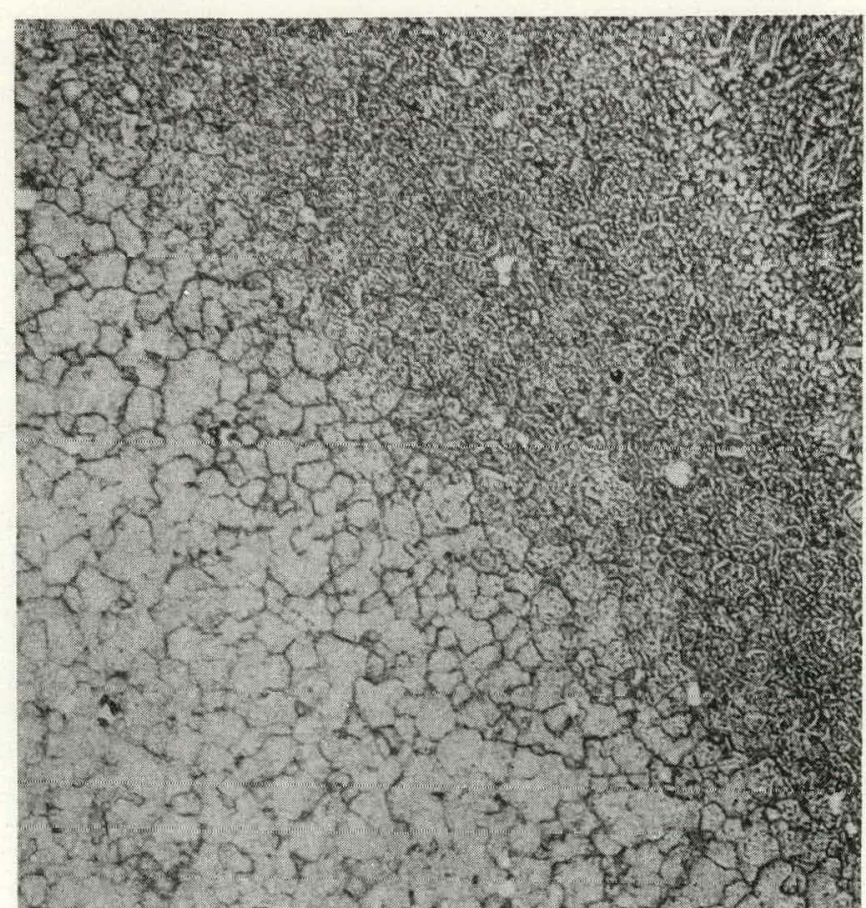


RFP-2033

Figure 6. Photomicrographs of Specimen Number 31. Solution quenched, overaged, and machined after welding.

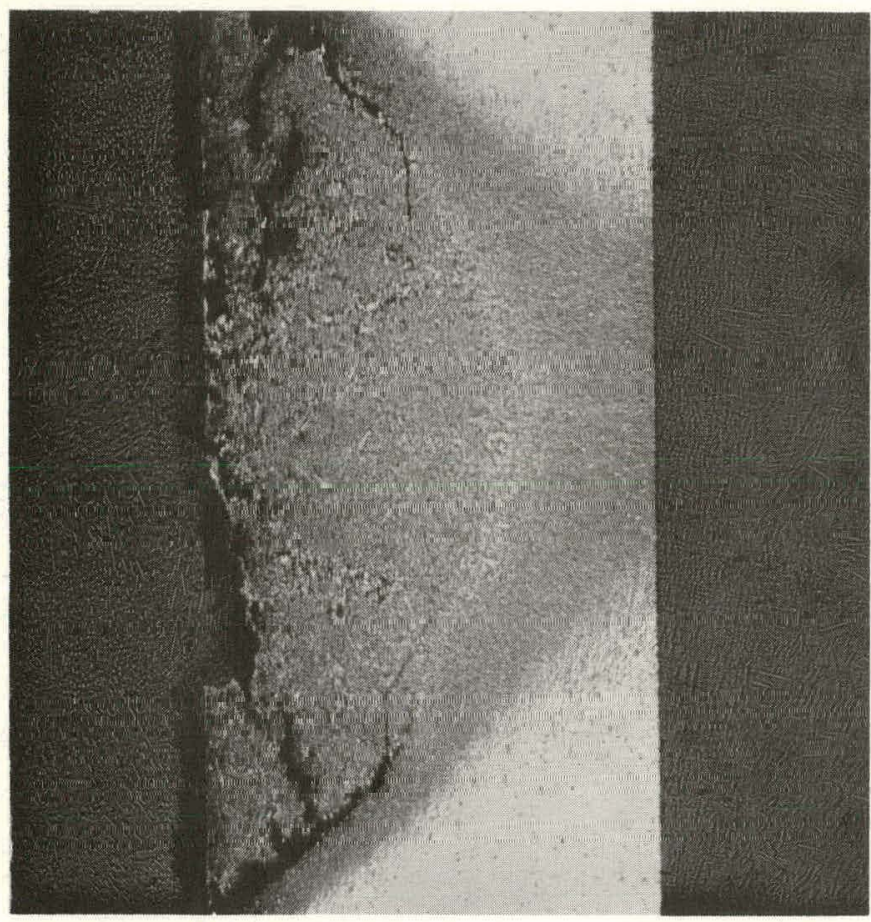

Figure 6a. Note the corrosion along bond line and within weld. 20X.

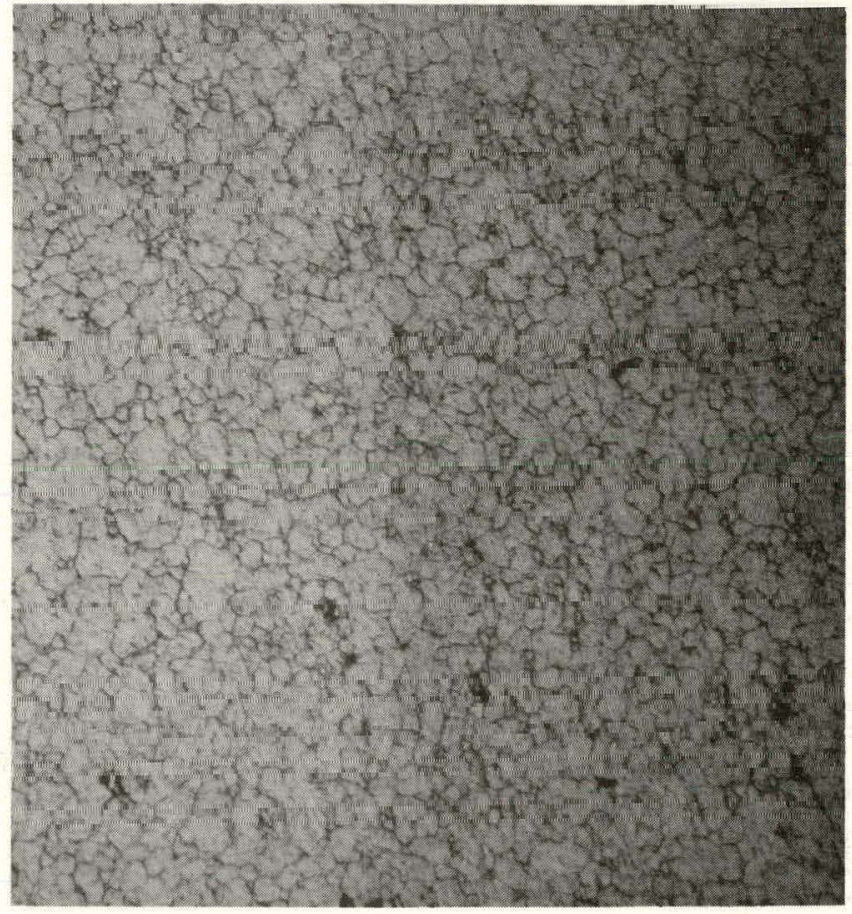

Figure 6b. Microstructure of parent metal. 100X.

Figure bc. HA $\angle$ microstructure. 100X.

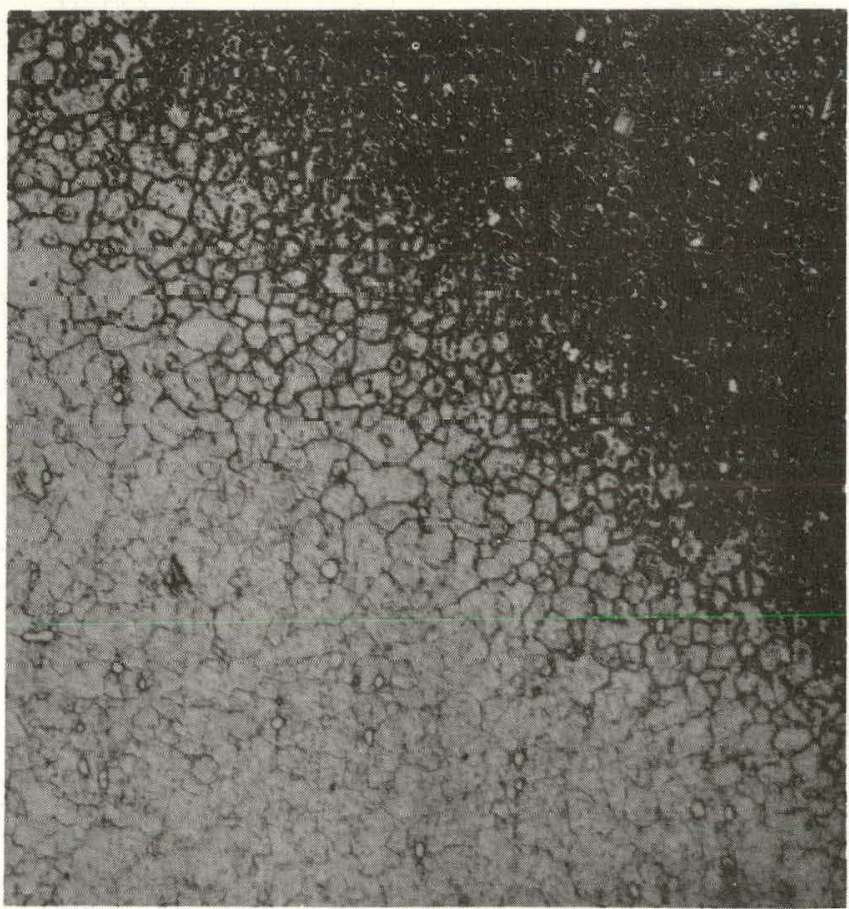


Figure 7. Photomicrographs of Specimen Number 42. Overaged and machined (no solution quench) after welding.

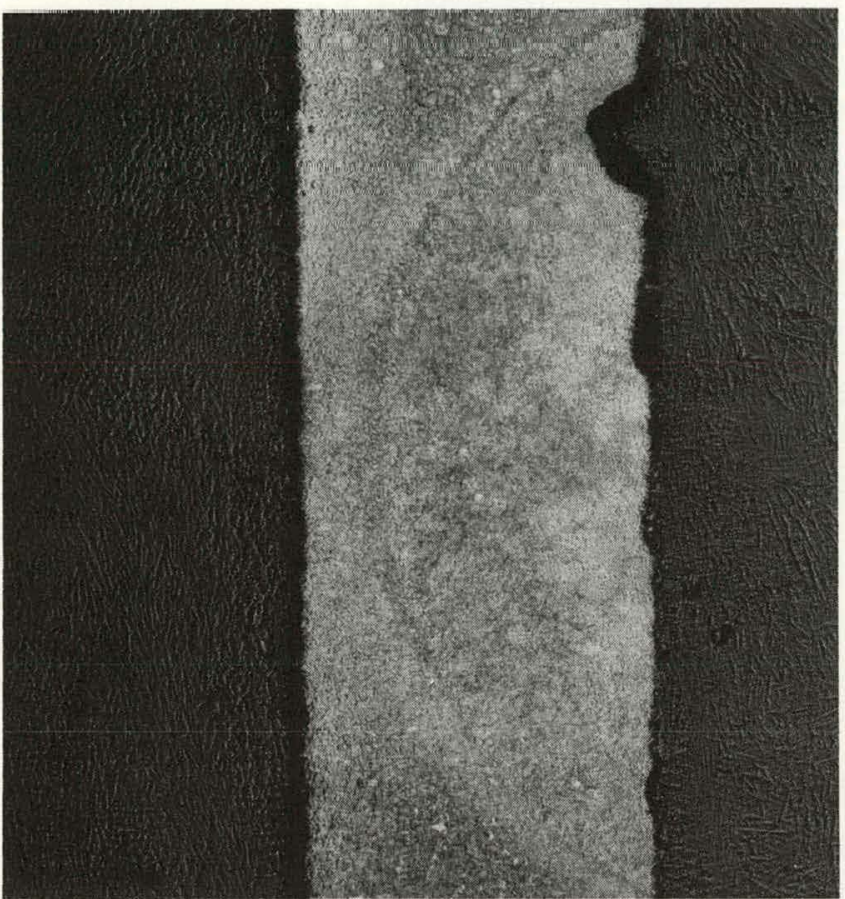

Figure 7a. Note the lack of full penetration and nearly uniform corrosion attack. 20X.

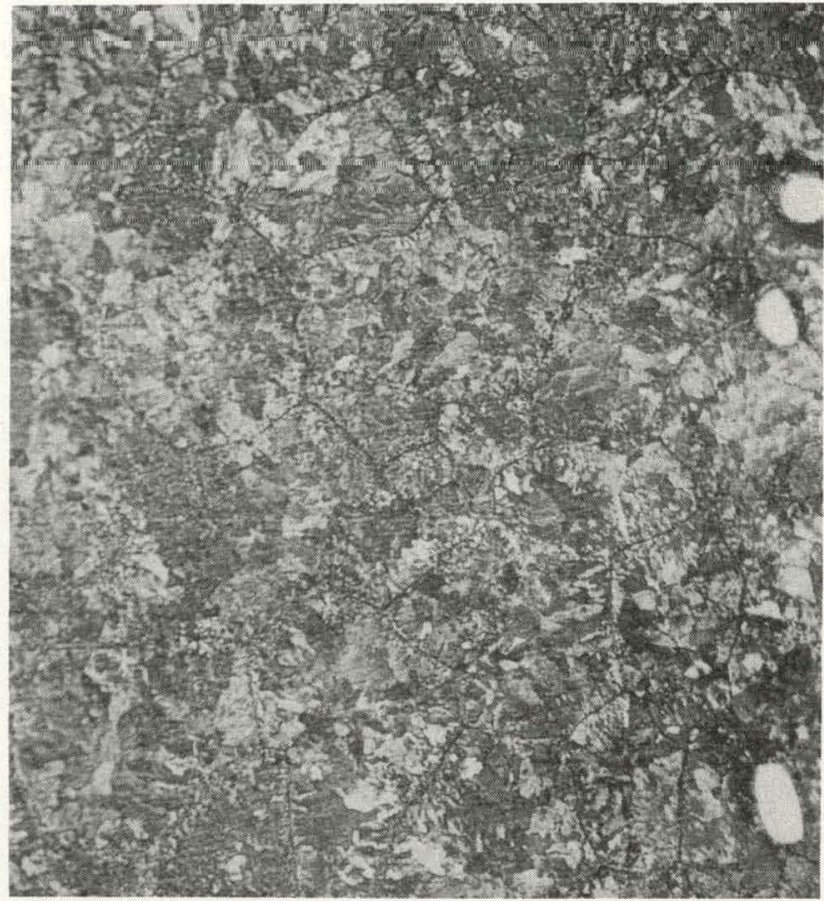

Figure 7b. Parent metal. Note the 2-phase structure within prior solution-quenched grains. $400 \mathrm{X}$.

Figure 7c. HAZ microstructure. 100X.

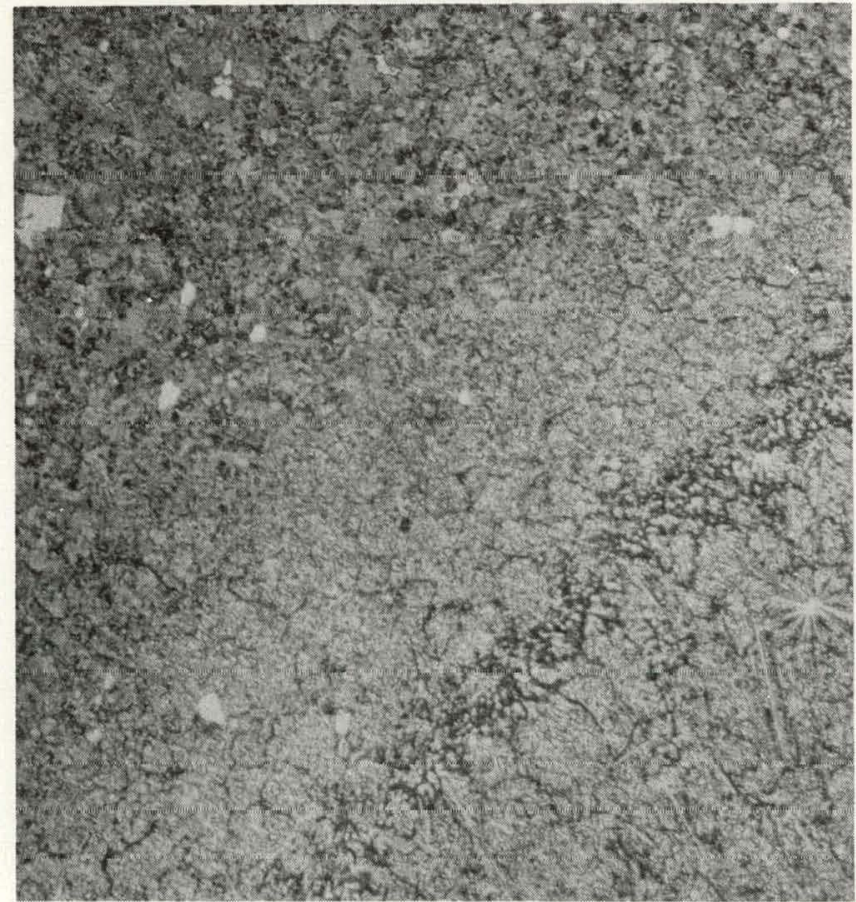


RFP-2033

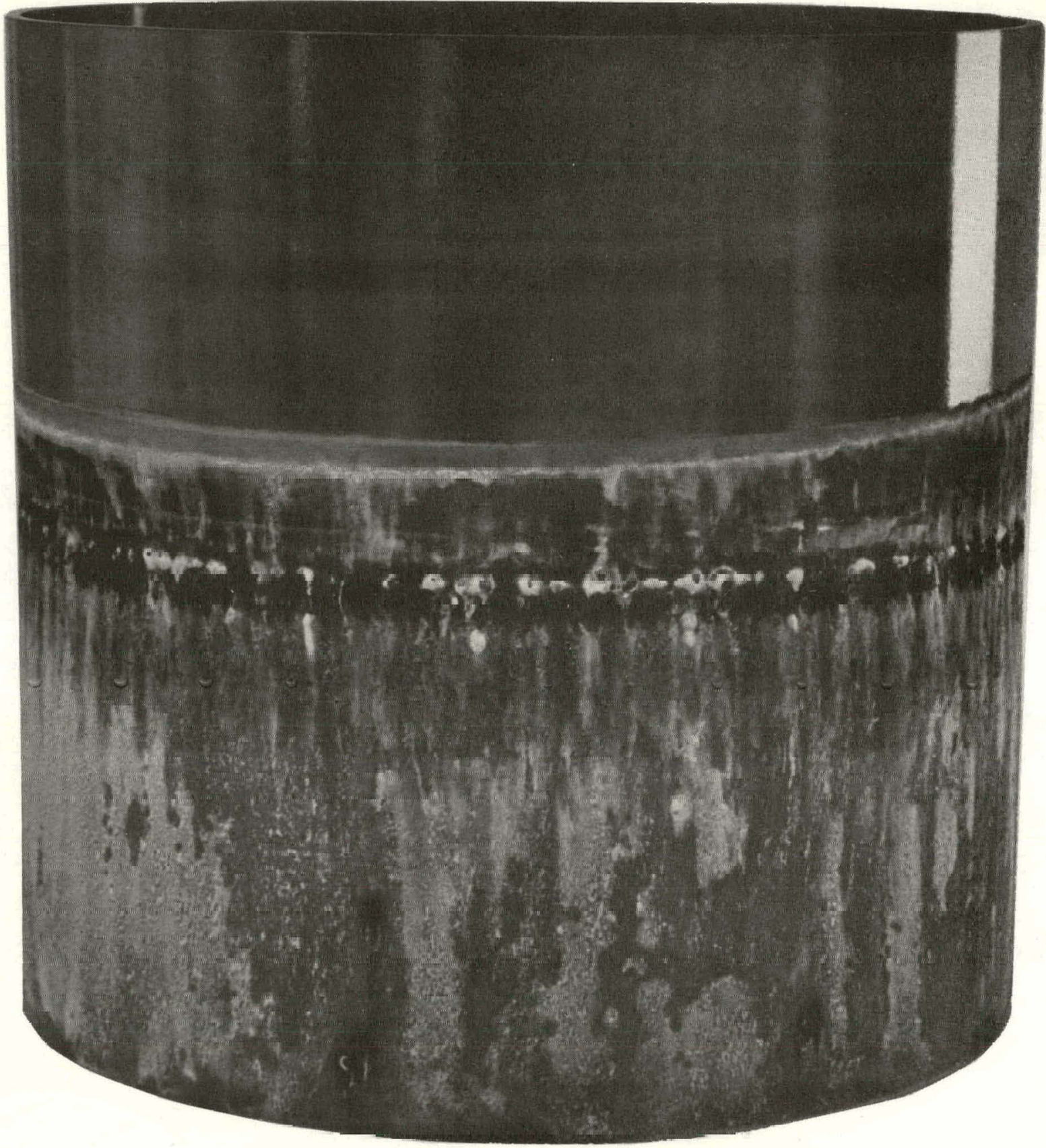

Figure 8. Welded Cylinder after 30 Days Immersion in Oxygen-Saturated Water Containing $50 \mathrm{ppm} \mathrm{Cl}^{-}$. 


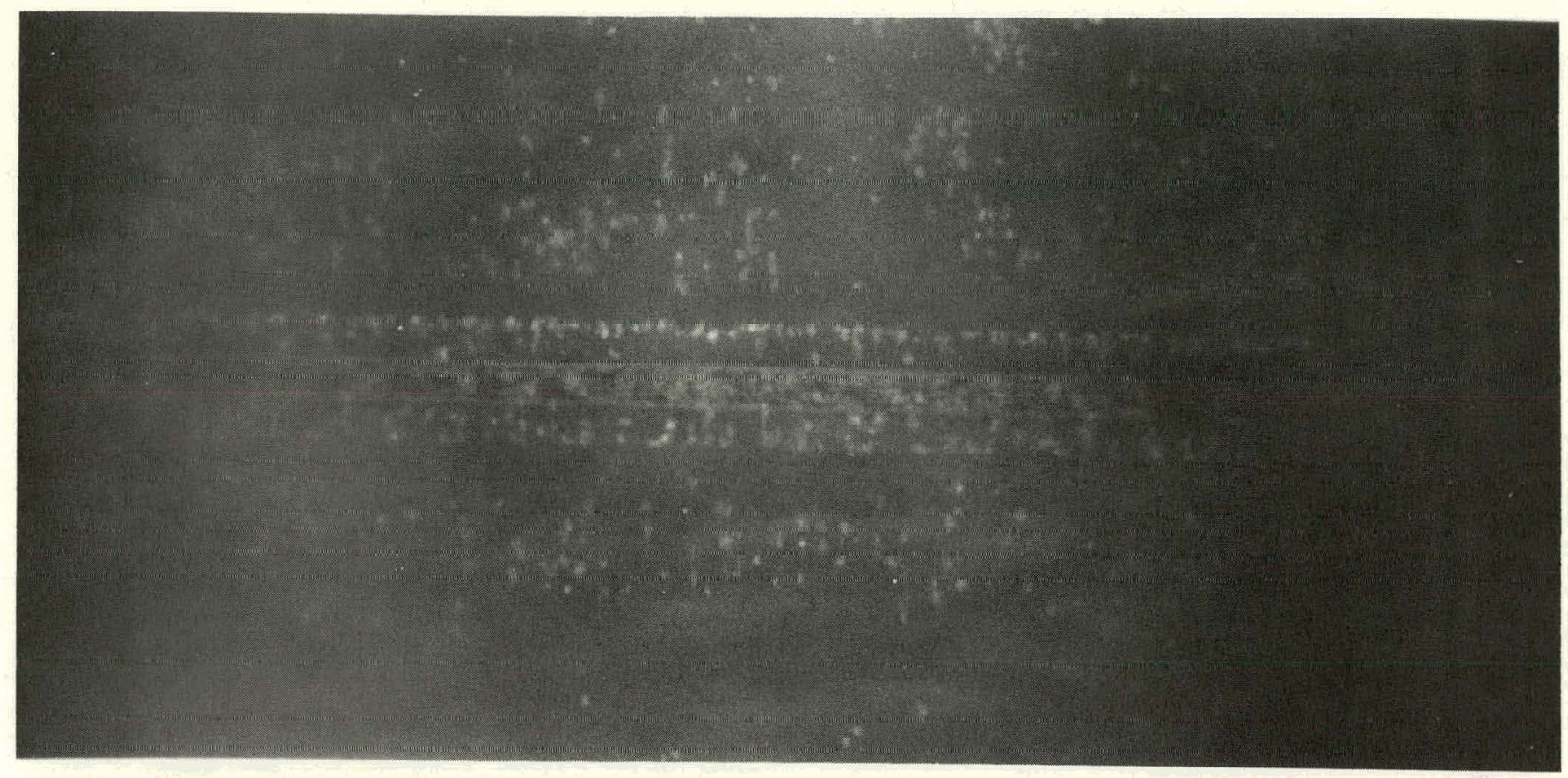

Figure 9. X-Radiograph of Specimen No. 39 (as-welded).

Figure 10. X-Radiograph of Specimen No. 24 (machined only after welding). 
RFP-2033

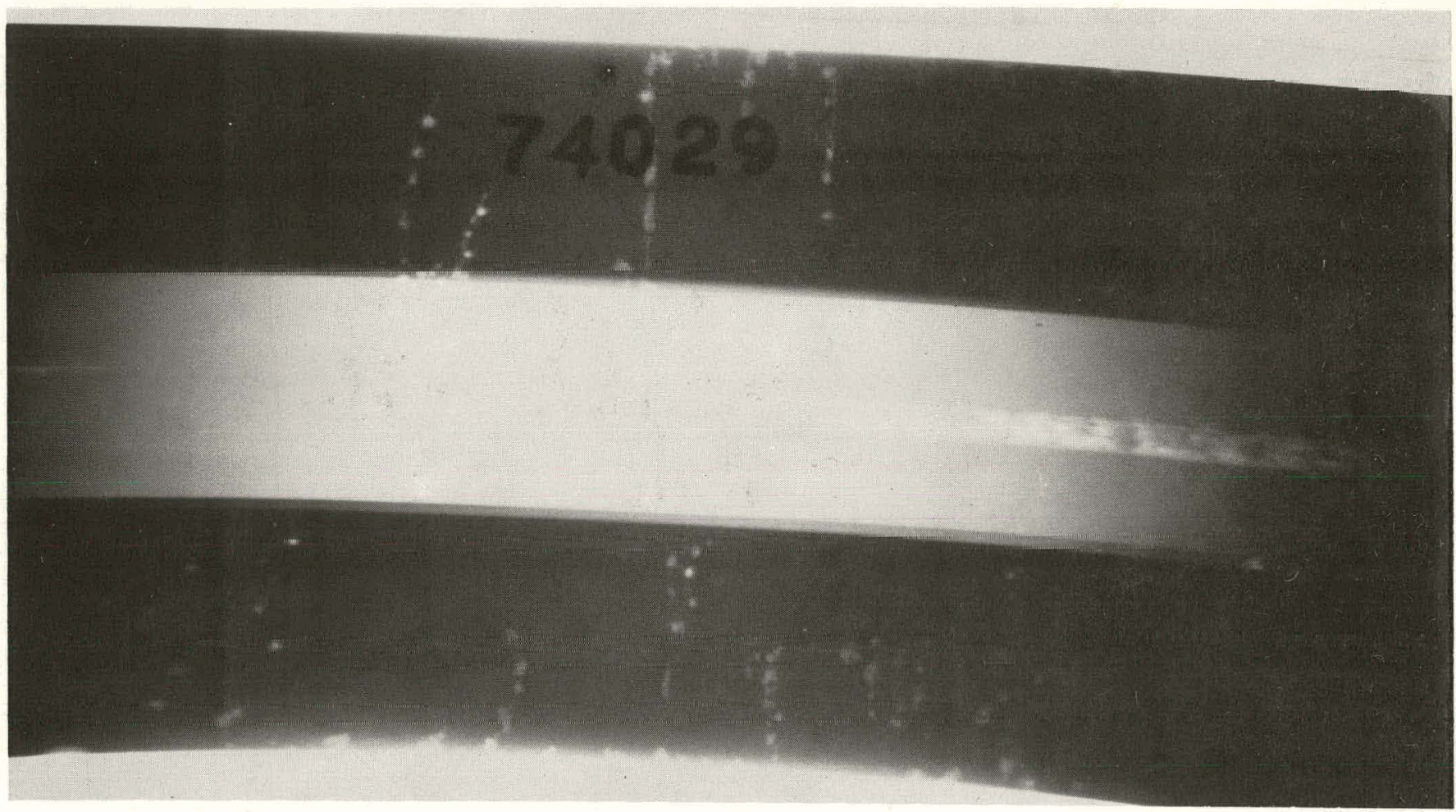

Figure 11. X-Radiograph of Specimen Number 29 (gamma-quenched and machined after welding).

Figure 12. X-Radiograph of Specimen No. 34 (gamma-quenched underaged, and machined after welding). Note light machined strip. 


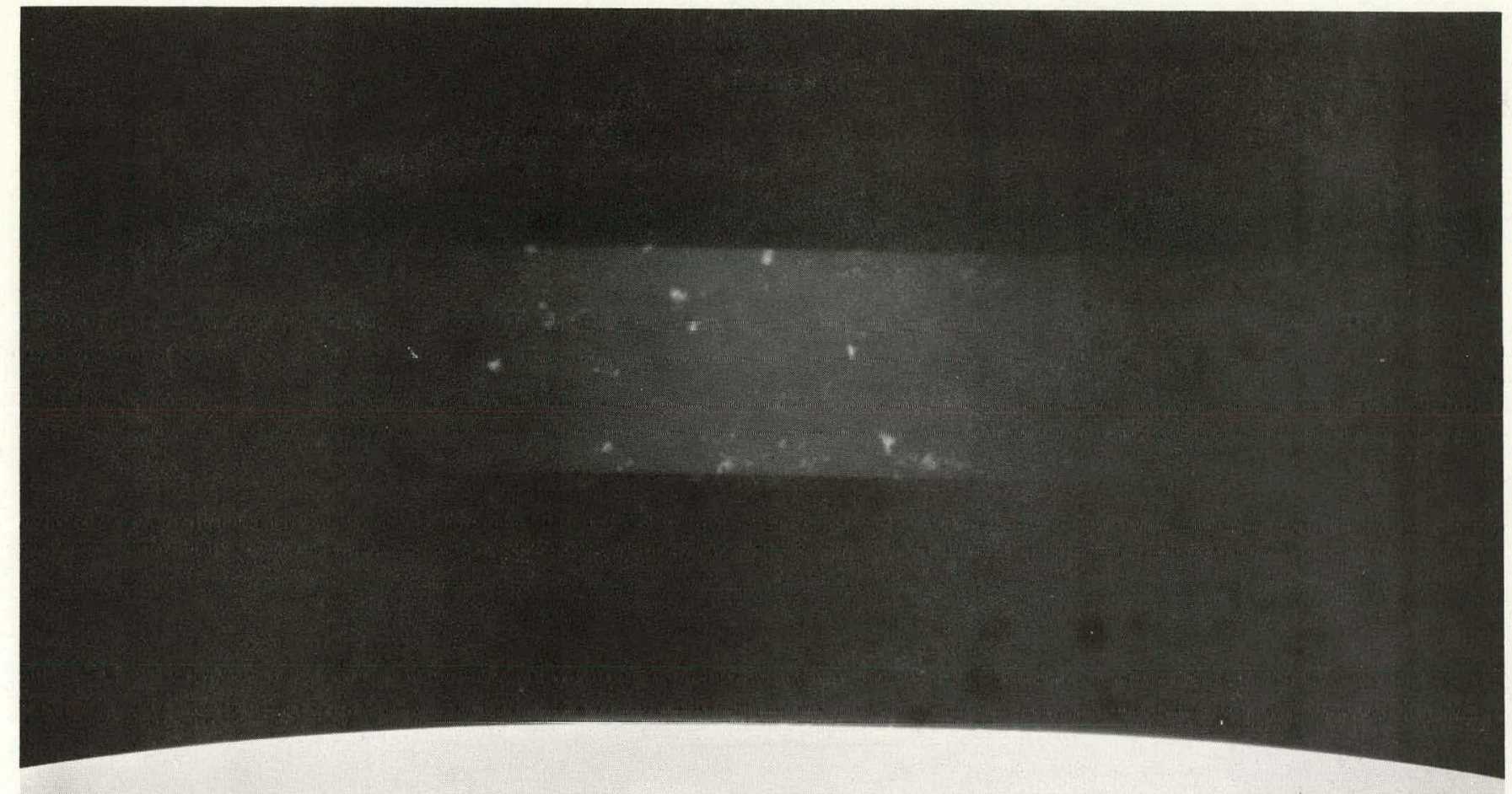

Figure 13. X-Radiograph of Specimen No. 35 (gamma-quenched underaged, and machined after welding).

Figure 14. X-Radiograph of Specimen No. 32 (gamma-quenched, overaged, and machined after welding). Note bright corrosion pit which has nearly penetrated metal.

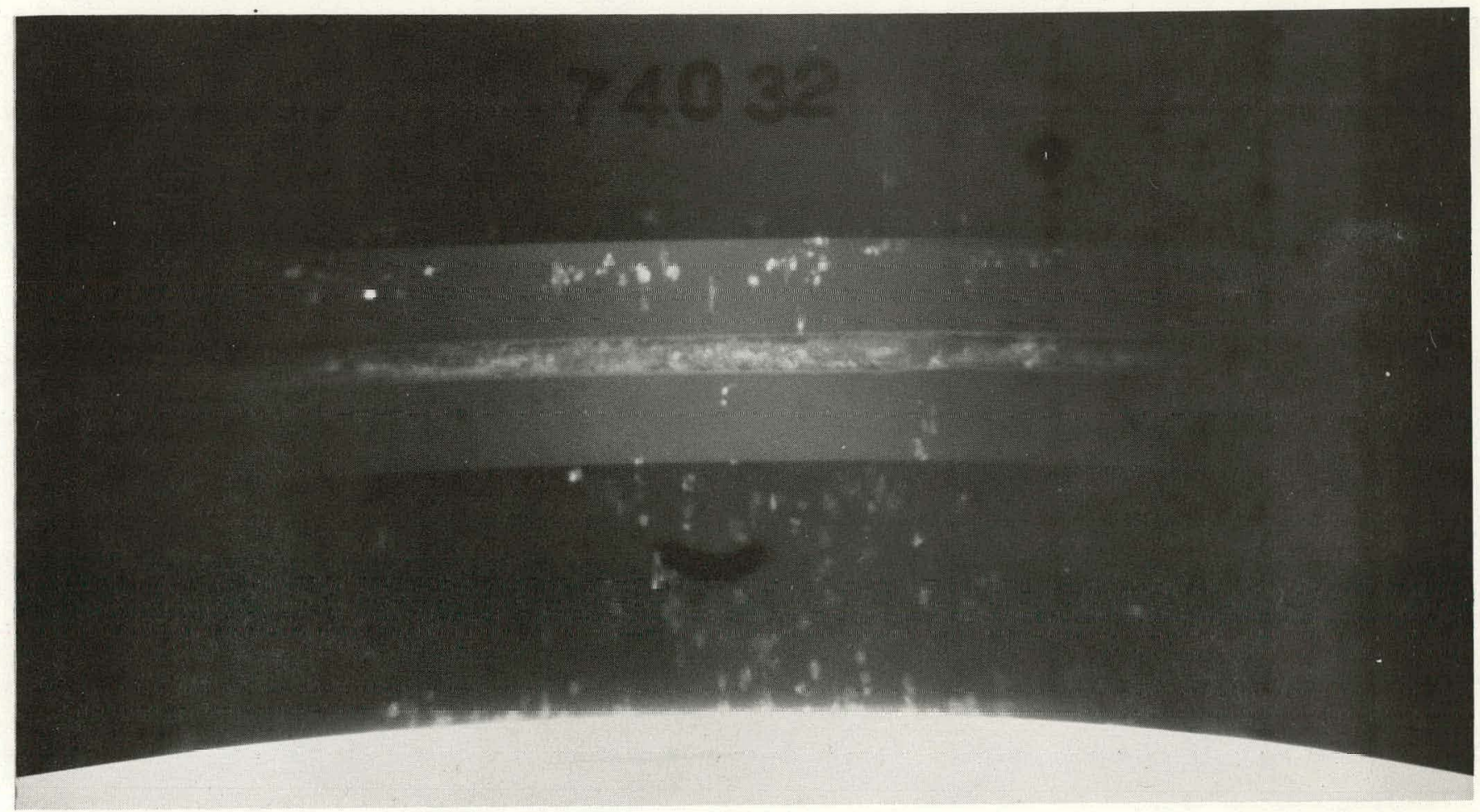




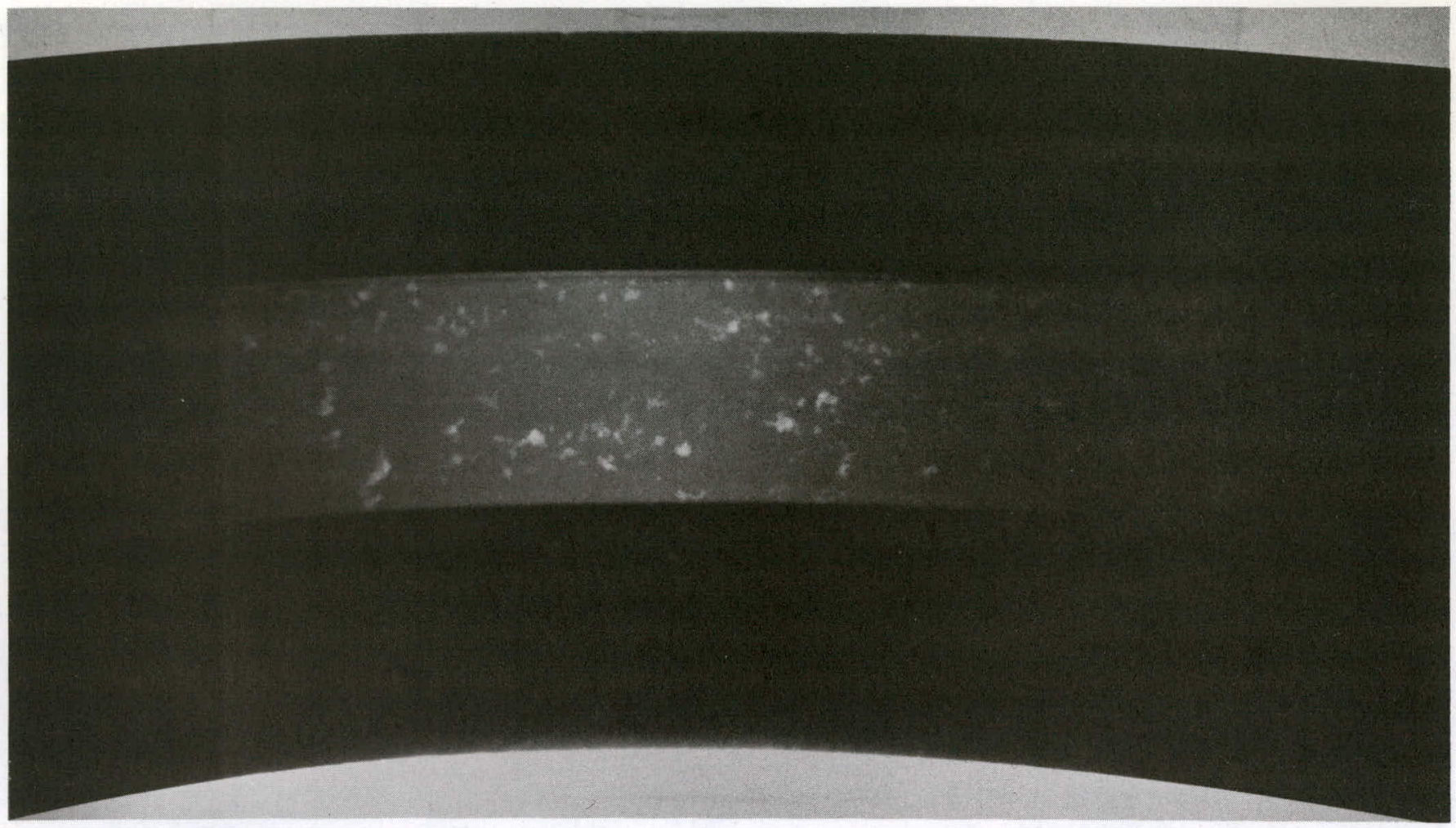

Figure 15. X-Radiograph of Specimen No. 44 (overaged and machined after welding).

Figure 16. X-Radiograph of Specimen No. 47: GTA tack welded.

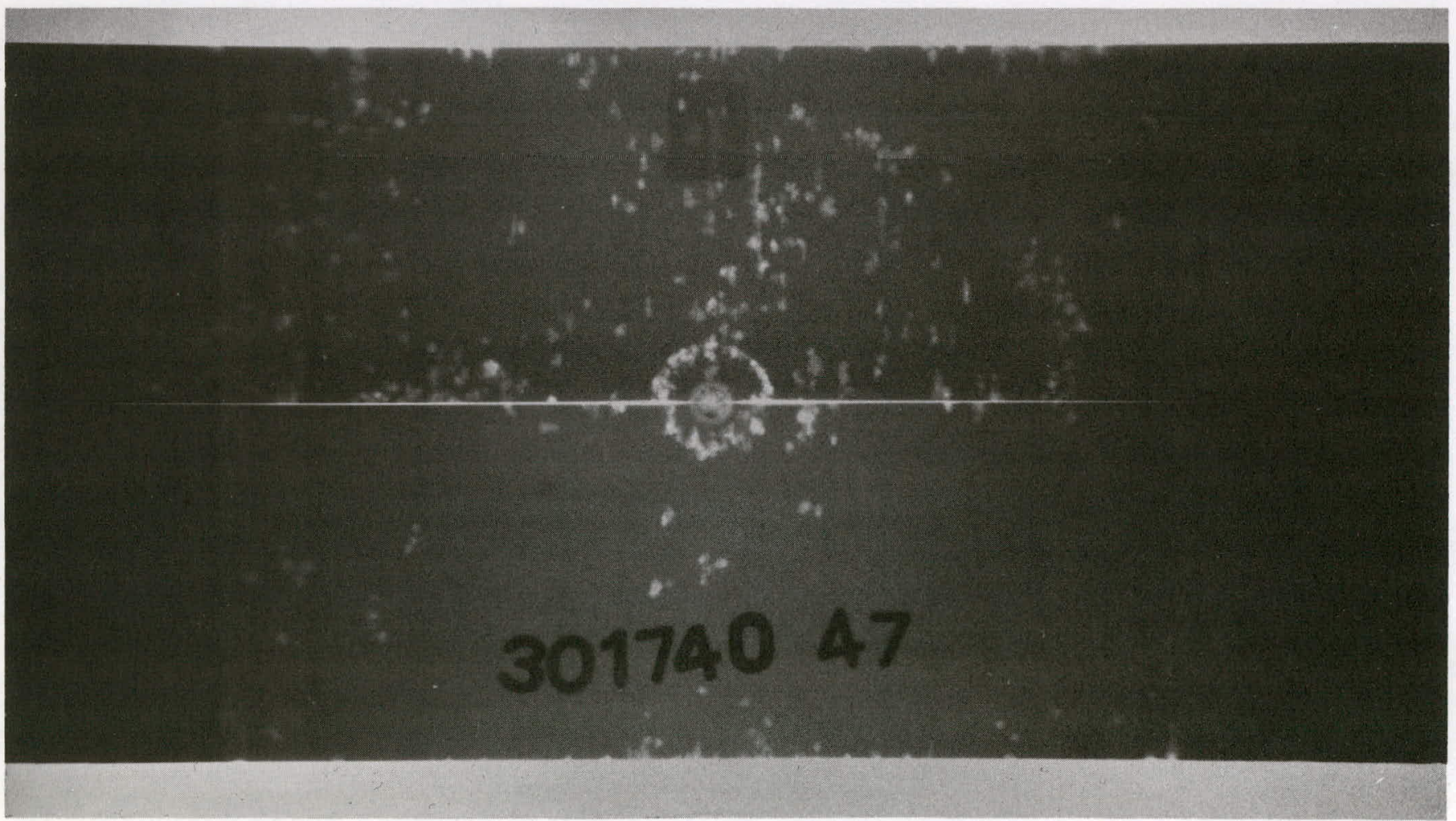




\section{REFERENCES}

1. J. M. Macki and R. L. Kochen, "Stress Corrosion Cracking of Aged U-4.5 wt\% Nb," Corrosion, 29, p. 153 (1973).

2. N. J. Magnani, "Stress Corrosion Cracking of Mulberry," Corrosion, 26, p 406 (1970).

3. C. A. W. Peterson and W. J. Steele, Delayed Cracking Study in U-7.5 wt\% Nb-2.5 wt\% Zr, UCID-15256, Lawrence Berkeley Laboratory, University of California, Berkeley, December 1967.

4. C. A. W. Peterson and R. R. Vandervoort, Stress Cracking in the U-10 wt\% Molybdenum Alloy, UCRL-7767, Lawrence Berkeley Laboratory, University of California, Berkeley, March 1964.

5. B. D. McLaughlin, L. L. Stephenson, and C. J. Miglionico, "Influence of Aging Time and Temperature on the Susceptibility of $\gamma$-Quenched U-5 wt\% Nb Alloy to SCC," Corrosion, 28, p 35 (1972).

6. N. J. Magnani, H. Romero, and C. J. Miglionico, A Study of the Stress-Corrosion Cracking Behavior of Mulberry (U-7.5 wt\% Nb 2.5 wt\% Zr), SC-RR-70-371,
Sandia Laboratories, Albuquerque, New Mexico, May 1970.

7. L. L. Stephenson, A Survey of Factors Which Influence Stress Corrosion Crack Initiation in Several Uranium Base Alloys, SC-DR-70-718, Sandia Laboratories, Albuquerque, New Mexico, October 1970.

8. N. J. Magnani, H. Romero, and C. J. Miglionico, The Effect of Chloride Ions on the Susceptibility to Stress Corrosion Cracking of U-71/2 wt\% Nb-21/2 $w t \% \mathrm{Zr}$ and $U-4 \frac{1}{2} \mathrm{wt} \% \mathrm{Nb}$ Alloys, SC-RR-70-860, Sandia Laboratories, Albuquerque, New Mexico, December 1970.

9. G. A. Witlow, Stress Corrosion of Uranium Alloys, AWRE-0-49/66, Gt. Brit. Atomic Weapons Research Establishment, Aldermaston, Berks, England, July 1966.

10. L. J. Weirick (Sandia Laboratories, Livermore, California) and C. W. Schoenfelder, article submitted for publication in Corrosion.

11. E. D. Brandon, private communication with J.F. Boland July 31, 1972. 